\title{
THE TEACHING MODEL ON SOCIO-CULTURAL DIVERSITY: LEARNING FROM INDONESIAN INTERNATIONAL KINDERGARTEN
}

\author{
SRI SULASTRI ${ }^{1}$ \\ Universitas Negeri Yogyakarta
}

\section{Abstract}

The socio-cultural diversity of Indonesia often leads to conflicts and disputes. Therefore, education on socio-cultural diversity is needed since early childhood. The kids' understanding of the concept of diversity would make them care about their presence in their diverse socio-cultural environment. The aim of this research is to describe the education model on socio-cultural diversity applied in early childhood education. This research uses the naturalistic qualitative approach and adopts Spradley's data analysis technique. The data of this research were obtained from the school foundation, headmaster, teachers, students, and parents in the early childhood education Golden Kids School, Surakarta. The data collection techniques used in this study are an in-depth interview, participative observation, and document analysis. The steps of analyzing the data include writing notes and categorizing the preliminary data, categorizing different themes, making matrix forms, and making a conclusion based on the matrix. The results of the study show that the practice of early childhood education that uses socio-cultural diversity approach through learning materials such as local songs, dances, and folktales from different regions, enables the kids to have the concept of knowledge and attitudes that respect diversity and highly uphold tolerance.

Corresponding author; email: ${ }^{1}$ l.srisulastri@gmail.com.

ISSN 0852-7172 (p) 2461-064X (e) 


\section{SRI SULASTRI}

Keragaman sosial budaya di Indonesia sering menyebabkan konflik dan perselisihan. Untuk itu pendidikan tentang kemajemukan sosial budaya ini harus ditanamkan sejak usia dini. Penanaman konsep keberagaman yang dipahami anak pada usia dini akan menjadi dasar pemahaman dan kepedulian terhadap lingkungan sosial dan budaya yang beragam. Penelitian ini bertujuan untuk mendeskripsikan penekanan sosio-kultural kemajemukan dalam pengembangan praktik pendidikan anak usia dini. Metode penelitian ini menggunakan pendekatan metode kualitatif naturalistik, teknik analisis data Spradley. Subyek penelitian terdiri atas yayasan, kepala sekolah, guru, siswa dan orang tua siswa di PAUD Golden Kids School Surakarta. Teknik pengumpulan data yang digunakan yaitu wawancara yang mendalam, observasi partisipasif, dan dokumentasi. Analisis data meliputi tahapan pencatatan dan pengelompokan awal, pengelompokan tema yang berbeda, dibuat pola bentuk matriks untuk melihat gambaran selurubnya, kemudianatas dasar pola yang tampak pada display data ditarik kesimpulan sehingga data yang dikumpulkan mempunyai makna. Hasil penelitian ini menemukan praktik pendidikan usia dini yang menekankan pada sosio kultural kemajemukan melalui materi pengajaran berupa lagu-lagu, tarian, dan cerita berbagai daerah sehingga membentuk konsep pengetahuan serta sikap yang menghargai keberbedaan dan menumbuhkan jiwa toleransi.

Keywords: early childhood education; education development; school; socio-cultural diversity; tolerance.

\section{Introduction}

Violence is always frightening, painful, and dreadful. Violence could happen in all aspects of human life such as religion, social, politics, economy, culture, and education. Violence even could happen in a very fundamental aspect of human life that is religion. One type of violence is called religious violence. Nowadays, religion is susceptible to any anarchic actions that legitimate intolerance and violence, although it actually teaches about love and peace for human beings. 
Indonesia, with the largest Muslim population in the world, more than 200 million or nearly 90 percent of its citizens are Muslim, is often praised as a model of moderate Islam. But currently, this country is facing a rise of radicalism groups and religious intolerance. The Indonesian Children Protection Commission has warned that radicalism teachings are being increasingly taught at every level of education, from kindergarten to university level.

Education is very important to fight against radicalism. The aim of early childhood education (PAUD) is to develop children's skills and attitudes without taking their right. Children understand the differences between the role of their parents and educational management. The educational management attempts to meet the parents' expectation by putting forward the knowledge while parents emphasize skills such as foreign language proficiency.

These conceptual differences triggered the establishment of PAUD by offering different programs to attract parents by using international label. The parents do not care about its high tuition fee. They just think that the international label of PAUD will provide better quality of education than the conventional one.

The rapid growth of the international PAUD can be seen from the increase of the society's interest so that they can exist, especially in big cities including Surakarta. People think that these international schools provide more values, particularly on children's intellectual development. These schools do not only develop cognitive intelligence but also the emotional and social intelligence.

Developing children's social intelligence by emphasizing Indonesian socio-cultural diversity is important because children were born and fostered in very diverse environments. Their un- 
derstanding of these diverse environments would make them more tolerant and appreciative to the differences. Thus, as they grow older and become adults, they would still be tolerant.

The children's tolerant attitude towards cultural diversity is cultivated through education. Therefore, early childhood education is supposed to be oriented towards cultural diversity. International schools with the Western concepts are likely not emphasizing on the understanding of Indonesian culture so that children are kept away from their culture. This is dangerous for their understanding against diversity.

As Ki Hadjar Dewantara (Dewantara 1977) said that humans have three psychological potentials, namely cipta (cognition), karsa (conation), and karya (psychomotor). A holistic human development requires balanced development of all potentials. The development that emphasizes too much on one potential will result in partial human development. Whereas, if education puts too much concern on cognitive intelligence, the students will be kept away from their community and not humane. Ki Hadjar also emphasizes on the socio-anthropological point of view by which humans are distinguished from other creatures because they have culture. One of the effective ways to make people more humane is by cultivating their culture. Only if they live in their own culture, they will really become human. A complete human being is understood as human completed by his own culture.

The culture, as well as positive values, and norms become the content of children's learning process at schools. They will behave positively in the society. Positive behavior in social relationship and environment can only be practiced if children have time to socialize with their environment.

International schools with the international teaching concept are not always appropriate for the social development of 
Indonesian's children. They will go apart from their family and live with the society as soon as they widen their understanding toward a new environment. The children can be affected by external influences without any parental supervision. Many negative things in the society such as violence against children, violence based on race, ethnicity, and religion (verbal or non-verbal), and even diverse ethics, politeness, and norms will influence the children's behaviors and characters.

Based on the observation in one of the international schools in Yogyakarta from February to March 2015, the teaching process of those schools is primarily focused on making the students independent. The learning model, strategy, and materials are oriented to make the children independent in their life. The values of the local culture were not developed because their teaching is Western-oriented. For example, there is no teaching about practicing traditional songs or dances. Children sang the songs in the foreign language. The songs also do not reflect the local aspects.

Therefore, children's knowledge regarding their own cultural diversity is so limited. This might provoke prejudices against other regional cultures that could lead to disunity among Indonesian cultures. The socio-culture that regulates person's behaviors in a group, makes a person feel sensitive to their status, helps them to know what others expect to them, and helps them to know what happens if they cannot meet other people's expectations. The socio-culture helps ones as individuals to take responsibility for themselves against the group (Mustadi 2011). The formation of children's attitudes and behaviors that is in accordance with the socio-culture of Indonesia is not only the responsibility of the parents but also the responsibility of the schools as the second environment. Therefore, schools become a place of the development of children's attitudes and behaviors. International schools in Indonesia have the same responsibility 
or developing children's attitudes and behaviors in accordance with Indonesian cultures.

Children should be helped to live in society because within the society there are values that children must understand. Personal development will help children adapt to their socio-cultural environment so that they can develop their potential. It can be useful for them and their environment.

Environment greatly affects the cognitive development of the children, thus socio-cultural teaching at the early childhood must be adjusted to their ability in learning. According to Sumirah in PAUD Assistantship Workshop, PAUD is not "force early education on children" by teaching things earlier. The teaching should be adjusted to the development stages of every child. Children should be taught through playing games so that their rights are protected. All of these must be done to enhance all children's potentials including motoric, linguistic, cognitive, emotional, and social by prioritizing freedom of choice, stimulating creativity, and instilling character values. Early childhood education provides a rich environment of sensory stimulation. It is designed in such a way so that children can develop their potential optimally (Morrison 2014).

An interesting and stimulating learning environment will help children to find their pleasure. Thus, the teacher does not have to motivate the children continuously to make them focus on learning as they already enjoy the learning atmosphere in the classroom.

This study uses a qualitative research approach. The data were collected through observations, interviews, and document analysis. The research setting was determined purposively that is the Golden Kids School, located at No. 214, Raden Mas Said Street, Surakarta. It is an early childhood education that is very popular among society as a fast-growing school. The research 
participants are the students, teachers, students' parents, and the stakeholder of PAUD Golden Kids School Surakarta.

The observations were carried out in three stages i.e. (1) the descriptive observation, aimed to describe the general situation of what happened in Golden Kids School, (2) the observation focused on the way to find categories, such as methods/strategies, approach, and assessment on the students' learning achievement, and (3) the selective observation, to identify the differences between observed categories which were then recorded by means of field notes and were further reflected.

The observed aspects are broadly outlined as follows (A) The subjects of observation are: 1 ) the teachers, including their teaching methods, coaching, and, assessment; 2) the students, including a) the learning process, and b) behavior; 3 ) other educational personnel, including a) the administrative staff, b) the security guard, and c) the janitor. The other aspects include services to students and the parents/guardians of students; (B) Observed artifacts including: 1) educative learning kits, 2) children's playing media, 3) learning environment, including the classrooms and the environment outside the classrooms, 4) the history of the school establishment, 5) the school dynamics, 6) thoughts: ideas, visions, missions, goals and school institution components, and 7) the leadership model, representing the dynamics of the school leader, the organizational structure, and culture.

The respondents in this study include the school principal or the manager, the teachers, the students' parents, and the Golden Kids School foundation management. The techniques in collecting data in this study were in-depth interviews that were documented in the form of recording, videos, and notes as the concrete evidences of the research findings. The author uses Spradley's interpretive data analysis technique (Spradley 1997; Miles and Huberman 1992) that involves disciplinary testing, creative 
understanding, and careful attention for the research objectives. The data of the interview were conceptualized through a dialogue card. The results of the dialogue card testing were presented to find out the emphasis of the diversity in the teaching process.

The field notes and the analysis results of the data of the Golden Kids School were systematically compiled based on the coding to provide a sharper description of the results obtained and to facilitate the tracking of the data collected when necessary. To see the results of the summary more easily, a matrix was created. In the pattern of the matrix, the whole description of certain parts of the research findings can be seen clearly.

Various procedures were used to reduce the possibility of errors interpretation including the data collection, which was attempted to reach the saturation point of the data called triangulation. Triangulation techniques refer to processes of perception utilization to clarify meaning, verify the possibility of repetitions of observation or interpretation. However, it must be on the principle that no observation or interpretation is $100 \%$ repeatable.

In this research, the two methods of the triangulation technique were used: a) Triangulation sources, to collect and compare data obtained from one informant or respondent with those from other informants/respondents. The results of the interviews with the principal of the school were confirmed to the vice principal, teachers, and so on. b) The method of triangulation was done by comparing the data collected

Karwati (2014) in her study entitled The Development of Learning by Emphasizing Local Culture in Young Children emphasizes that the children who are given educational stimulation by playing local culture games can preserve and nurture a sense of love for his own cultures. Similarly, Nyoman Sudiani (2015) 
THE TEACHING MODEL ON SOCIO-CULTURAL ...

in her study entitled Character Education through Gending Rere: An Ethnography Study on Young Children in Tenganan Pengringsingan Traditional Village, Karang Asem Regency, Bali Province found that Gending Rere, sung when lulling, bathing, feeding, and accompanying children in playing, can form social characters that foster the attitudes of helpfulness, willingness to sacrifice, loving the homeland, and caring about the environment.

Wulandari and Hurustyanti's (2016) study entitled Character Building on Young Children through the Optimization of Traditional Games Based on Local Cultures mentioned that local-culture-based traditional games can improve the quality of young children's honesty. Thus, based on these studies, it can be said that local cultures can form the personal characteristics of young children.

A study by Eka Sapti, et al. (2014), entitled Character Recognition Training for Young Children through Local Folklore for non-formal PAUD Educators in TPA/KB/SPS in Sleman District affirms that folklores can improve educators' understanding of young children's characters and enhance their skills in storytelling. This study proves that teachers in early childhood education need to be equipped with the ability to tell stories so that the stories can be easily understood by young children. Storytelling is one of the most interesting media for children, however the teacher must be able to convey the meaning and content of the story to the children.

One of the strategies to make children enjoy the learning process is by creating an interesting learning atmosphere, for example through playing games and telling stories. Media have a central role in the provision of education. In addition to exploring learning, playing also helps children to know themselves, know who they live with, and recognize the environment in 
which they live. Children's playing environments, both physical and psychological, values, and norms, greatly influence the learning process they are taking part. Therefore, children's learning environment is a place that can develop their socio-cultural potential through their interaction with the people around them.

Children's learning environment will trigger their social development. According to Monks and Knoers (Monks, F.J. and Rahayu 2006), social and personality development starts from the pre-school to the end of school age. It is characterized by the widening of the social environment. There will be a distance between children and their family and they will become closer to those other than the members of their society.

Lev Vygotsky stresses the importance of socio-cultural patterns and social interactions. Both play a fundamental role in cognitive development. Vygotsky also believes that children formed their words through interaction with their culture and society. As mentioned by Vygotsky (Salkind 2004) that the cultural development of the children takes place at two levels: first, on the social level, and later, on the individual level; Second, between people (inter-psychological) and then inside the children (intra-psychological).

Cognitive, social, or language development cannot occur as a result of maturity but rather based on what the children learn. According to the findings of the research on children with different ages and cultures, Vygotsky concludes that some of the most universally perceived development could be acquired at a certain age, such as the ability to use an abstract approach, resembles the external growth, namely particular learning experience associated with formal schooling (Roopnarine 2011) .

According to Lev Vygotsky, the socio-cultural theory shows the influence of social and cultural interaction on human development. The social interaction affects children's thinking de- 
velopment and hence their behavior. In the social context, the behavior is built upon cultural differences. Besides, children development actually mediates their interaction with others and their language. Children's mind can develop on occasions that they are engaged in specific cultural activities, such as education, family rituals, and community activities (Salkind 2004)

There are four underlying principles of Vygotsky's theory. First, children build their own knowledge. Children do not only shape their will and needs, but they also shape the type and quality of knowledge they needed. For example, the need for reading (set in the right environment) will encourage children to seek opportunities to learn how to read and improve their reading skills.

Second, children development cannot be separated from their social context. The process of development is based on maturation and environmental effects. The process occurs in a particular social context. In addition, the relationship between culture and thought is important. The culture influences what and how children think, and how different cultures give different effects.

The next principle is that learning can direct the development. It means that learning may become a preparation for development. Thus, teachers who assign tasks to children really mean to guide them toward an increasingly complex development.

The final principle is that language plays a central role in mental development. This means that language is a cultural means that allows the children's mind to grow and develop. Language provides labels for new ideas that allow children to expand those ideas in new areas.

Based on the aforementioned principles, the researcher decided to study the modeling of socio-cultural diversity in the 
development of early childhood education programs in the international PAUD Golden Kids School in Surakarta. It is a city with rich culture governed by Central Java Governor Regulation No. 9 of 2012 on Language, Literature, and Javanese script. In Chapter III Article 5 of the regulation stated that the Javanese Language class has to be integrated into the school curriculum with the time allocation of at least 2 class hours for every week in every grade. Javanese Language class is only taught from the elementary school level. However, Article 13 of the regulation has already stated that all school levels in Central Java are required to allocate the subject in the curriculum. It means that Javanese Language should be taught at all school levels, including early childhood education or PAUD.

After reviewing some previous studies, author found that the studies on deradicalization in early childhood are still limited. Whereas the learning of religious understanding for children is very important since the most elementary school level. The previous studies did not focus on student diversity and just offer of a mono-culture solution. This is different from the practice of learning in the school with cultural and religious diversity. Through this research, the writer initiated the ideal concept of deradicalization based on learning practices applied in PAUD Golden Kids School in Surakarta. This concept can be a role model for the learning on diversity for other schools. The model is the integration of learning concepts with socio-cultural diversity understanding.

\section{Golden Kids School: From Zero to Hero}

There are five classes in the Golden Kids School and the building consists of two floors. The second floor is provided for Kindergarten I (4-5 years old) and Kindergarten II (5-6 years old). The first floor is for Nursery I (2-3 years old) and Nursery II (3-4 years old) as well as Toddlers Class (1-2 years old). In 
dealing with the method, the school implements various teaching methods. One of the methods is BCCT (Beyond Centers and Circle Time) which is the development of the Montessori Method, High Scope, Red Star, and Reggio Emillia. This method is used to train children's discipline in early childhood with the freedom to explore their ability and interest in certain fields such as music, acting, and painting. According to the founder of the Golden Kids School, the institution was established because of the awareness related to the importance of early childhood education to develop children's potential and intelligence through playing education games. Therefore, the slogan used in the Golden Kids School is From Zero to Hero.

Every class is taught by two teachers, the one acts as the main teacher and the other one as the teaching assistant. Teachers do not serve as the classroom teachers because every lesson provides a specific theme so that the teacher moves to another class after teaching in the previous one. For example, the lesson at the cooking center is delivered by Miss Yeye. After teaching, she will move to the next class. The aim is to make the children in the school familiar with all teachers in all subjects. Nevertheless, each class is controlled by one teacher who is fully responsible for the class. For example, the teachers of Nursery II are Miss Yeye and Miss Wanti. All the teachers at the Golden Kids School are addressed with the title "Miss" because in the Golden Kids School, two languages are taught that is Indonesian and English. The learning schedule uses one of the implementations of the Standard Operating Procedure, which is attached to the classroom wall as a reference for the arrangement of the teaching and learning activities. It is then possible for the schedule to be developed or changed when necessary. For instance, the preparation for art performances or other activities requires practices so that the class schedule may not be the same as the previous one. 


\section{Learning Design: Promoting Tolerance and Cultural Diversity Awareness}

The traditional dance lesson is one of the activities which can develop children's aesthetic aspect. Children can develop not only their aesthetic sensibility but they can also love and respect to their own culture. In addition, singing local/traditional songs can enhance their local language competences even though in formal situation, children communicate in two languages that is Bahasa and English.

The traditional songs and dances learning are performed in special events to celebrate Kartini and Children's Days. The performances are aimed at developing children's self-actualization and improving their courage as well as their self-confidence. The children wear traditional costumes in accordance with the songs and dances in their performance. Their understanding in the traditional songs and dances will make them understand the variety of culture and diversity.

One of the dances taught by Miss Yeye is originally from Papua, namely Yamko Rambe Yamko. Children coming from different ethnic groups took part in the dance practice obediently. They paid attention to the instruction told by Miss Yeye diligently and enthusiastically. The children looked happy when being asked to follow Miss Yeye instruction. Miss Yeye was assisted by Miss Nining to help children who had difficulties in following her instruction. The practice was done several times, and the children seemed to be happy and excited.

After the practice, Miss Yeye told the children about the history of the dance. It represents the sadness of Indonesian people after the war against the invaders in 1945. When telling the history, Miss Yeye opened a dialogue with the children. The dialogue contains some values related to peace, war avoidance, food, and costume differences which can be easily understood 
by the children because the teachers told them using simple language, for example, "we should love each other, and we should not argue with other people who have different languages." The dialogue was being conducted during the break where the children were sitting down freely while having the dialogue and listening. Sometimes, they made fun of their friends, and the teacher let them did so as long as they did not disturb the others.

On different occasions, the children learned traditional songs, i.e. Padang Bulan song which is originally from Central Java. Children made a circle and sang the song together. Later, one of them should stand in the center of the circle. Every child took a turn to be the center of the circle, so there would be no child who dominated the activity. After singing the song, the children and teacher sat on the floor while taking a break and listening to the song translation and meaning. Miss Yeye told that Padang Bulan is about beautiful scenery at night. Children were told to go to bed earlier but they should also enjoy God's creation. Each child told their experiences related to the moon, full moon, and the color of the moon, which are concluded by the teacher as the God's creation we should be grateful for.

The teacher instilled Indonesian society behaviors, including helping each other, caring for others, and respecting others in the teaching-learning process. The social behaviors represented Indonesian customs and cultures. The students were also taught to help one another in every occasion and activity so that it will become children's character. The activity representing Indonesian custom and culture was presented in the way the children were talking to a friend who did not bring water to school. After singing together, the teacher allowed children to take a break and have some drinks. Children gave water or snacks to those who did not bring it.

Moreover, children coming from different ethnic groups usually have different understanding about politeness. There 
was a condition when a child was using his left hand to give something, and it is considered as something acceptable. The teacher gave him advice and taught him to use the right hand. Children were taught how to behave and respect others especially the ones who are older. The teaching of ethics will build children's understanding and social behavior in the children's social life. Children practice the ethics in their family, in their smallest social environment, and later in the more extensive environment called the society.

Indonesian cultural diversity was taught by the teacher through folktales. The teacher told a story about Malin Kundang, a story from West Sumatra. During the storytelling activity, the teacher had a dialogue with the children. The teacher asked "Who should we respect?", Parents replied to the children. A dialogue that is related to the matters of respect, appreciation, and love of parents represents respect to God too. Children seemed to be enthusiastic in listening to the West Sumatran story. The teacher used pictures during the storytelling activity. As a result, the children asked about the clothes worn by the people in the story.

A story has become an effective medium to instill good values to develop children's behavior. By listening to stories, children can easily understand the differences between good and bad values as well as the differences between the things they should do and the things they are prohibited to do. The stories from various Indonesian customs and cultures could enrich children's knowledge and instill the concepts of Indonesian cultures that possess good values and nobility.

\section{The Teaching Model on Diversity}

Children's life in the family has formed simple social relationship. It is a relationship between the children and the members of their family. As a larger environment, school life develops 
new knowledge related to a larger relationship and the culture of the school. The culture might be different from their family customs, as the smallest social environment.

It is stated in Vygotsky's theory that children will observe and imitate the behaviors they see. Thus, the school environment has become an important place to develop children's behavior. The teachers play a role to help children understand their new culture, but it does not necessarily mean accelerating children's maturity in understanding the culture they see. The teachers guide, direct, and help children to understand their social life. Children will develop their knowledge about culture they have seen and experienced with the teachers' guidance.

The emphasis on socio-cultural diversity starts from children's smallest environment that is their school. The ethnic and racial diversity of the Golden Kids School portrays a socially diverse miniature of Indonesia. The values of friendship and respect to others are instilled in children's daily behavior. The children are given an understanding that their peers have different skin colors, mother tongues, and behaviors. Further, they are taught about common attitudes to respect others by being polite, helpful, and appreciative. These concepts are similar to those of Karwati (2014) in her research entitled Learning Development by Emphasizing Local Culture on Early Childhood. In her research, local culture is believed to have the ability to foster love for one's own culture and encourage one to preserve it. The emphasis on socio-cultural diversity is an effort to foster love toward social diversity due to the cultural diversity. Every ethnic group in Indonesia has different traditions, ways of life, communication patterns, social life patterns, and cultures. These differences are sometimes problematic and threatening the unity of Indonesia. Thus, starting from the early age, children should understand that there are people coming from different cultures. 
The teaching of cultural diversity is carried out through the teaching of Indonesian local dances, songs, and stories. The teaching on diversity is not integrated into learning materials but it becomes an independent subject. The aim of teaching cultural diversity is to instill values and concepts that Indonesia consists of different ethnic groups, cultures, and social lives. The social and cultural differences should not be the cause for national disputes and conflict, but they are national treasures that should be preserved. Students at the Golden Kids School are taught that friends with brighter skin, slanted eyes, or reddish hair are the same. They are all Indonesian young generation.

The learning media used to teach socio-cultural diversity include songs, dances, and stories adjusted to the early childhood cognitive development level. Playing is the learning orientation at this level. Psychologically, singing, dancing, and voicing one's thought in the told stories are beneficial for children's emotional development. Thus, the use of songs, dances, and stories coming from various regions does not only promote the concept of social and cultural diversities but also gives benefit for children's social, emotional, cognitive, and moral development.

Miss Yeye confirms that the purpose of using local dances as learning media is to introduce children to local cultures. Introducing local cultures to children is beneficial to foster love for local cultures, and to develop children's aesthetic values. Love for local dances and stories strengthens the love for the nation. Children are given an understanding that all local dances from any region in Indonesia portray the Indonesian way of life which is full of wisdom.

Introducing local songs to young children also evokes love for the homeland. Its functions are to filter children's inclination toward foreign culture. The love for their own culture could awake their awareness that their cultures could not be claimed by 
other countries. Children are taught that every region has its own beauty portrayed in the song lyrics. The media of socio-cultural diversity learning is like using tembang gending (Javanese traditional songs accompanied by traditional musical instruments). The use of tembang gending is similar to the research conducted by Nyoman Sudiani on "Character Education through Gending Rere, an Ethnography study on Young Children in Traditional Village, Karang Asem Regency, Bali Province" (Sudiani 2015). It is easier for children to understand and get immersed to music and songs. The diverse songs sung by children will permeate their souls. The song lyrics about the beauty of nature and the greatness of God will evoke the feeling of love for their culture as reflected in the song, even it is written in a local language.

Local stories may reflect the social life, customs, and natural resources in certain areas. It evokes a sense of belonging because those areas are parts of Indonesia. Local stories also evoke a sense of wonder at God's creation that leads to the effort to preserve them. Further, local stories can be the media to nurture children's aesthetic needs. The use of local stories as the teaching media at the Golden Kids School is similar to the research conducted by Eka Septi C., et.al entitled "Character Recognition Training for Young Children through Local Folklores for non-formal PAUD Educators in TPA/KB/SPS in Sleman District". In this research, Eka Septi C, et.al said that stories are teaching media that provide insights to children's character, Teachers should have adequate storytelling skills to carry out this learning activity so that the children can fully understand the messages. Miss Yeye who conducted this activity is very communicative and interactive. Children are not only fully immersed in the stories told by her but they can also identify the values independently. In conclusion, the use of local stories to teach socio-cultural diversity is deemed successful and children can understand the socio-cultural diversity. 
Children's aesthetic needs become the media to express themselves. Self-expression may elevate children's creative processes. According to Reggio Emilia, creative arts experiences affect cognitive, social, and emotional development.

The teaching method applied at the Golden Kids School is in accordance with Reggio Emilia's method, i.e. the arts-based curriculum. For instance, arts learning develop children's aesthetic values. Aesthetic learning is conducted by emphasizing the socio-cultural diversity.

Javanese songs are certainly different from the common songs. It is because they use the local language that is the Javanese language. Singing and reciting in the Javanese language will foster a sense of love for Javanese songs. Children should have been instilled a willingness to love Javanese songs from early ages. Likewise, children can interpret other local songs which are sung in the correct pronunciation and utterances. Thus, children begin to know the pronunciation, utterances, and the meaning of the lyrics of the local songs though in a very simple way.

The traditional dances introduced are not only limited to Javanese dances but also other dances from other areas in Indonesia. The introduction to the local cultural diversity, especially traditional dances, will establish children's understanding that Indonesia is rich in cultures. The cultural diversity is the nation's treasure that must be preserved.

Children know how to dance by dancing together under the guidance of their teachers. Children were dancing happily by moving their hands and feet cheerfully so that they can develop both their artistic creativity and their aesthetic value.

Children will develop their muscles well because of the movements. In addition, they also will develop their aesthetic value, such as the subtlety value and the softness of the soul. They will grow into humble and gentle people who love beauty 
and have an appreciation to work. Thus, children can develop their cognitive, psychomotoric and affective domains.

As an international school, the Golden Kids School adapts some teaching methods, although in the practice not all of these methods are adapted, only a few of them. Thus, the teaching process at Golden Kids School applies three learning approaches that is Montessori, High Scop, and Reggio Emilia methods. Children's development is influenced by biological and social development and this takes place naturally. Vygotsky argues that children's mental development is influenced by others and it will establish their knowledge. Children's interaction with the environment around them includes the relationship between children and their parents, children and their teachers, and children and their friends. These interactions do not only reflect what is seen from them but also establish their way of thinking.

Children's social behavior development can be seen from their daily life through their learning process. Therefore, teachers in the teaching process according to Vygotsky's viewpoint have three important roles: (1) building children's knowledge, (2) assisting children from being dependent to being independent, and (3) reinforcing, not accelerating children's development. Children build their own knowledge and are supposed to not passive about what happens around them. They also need the help from adults and even sometimes imitate their behavior. So, adults should provide assistance that leads to the children's independence. Children see their teachers who have a sense of love to the diversity of Indonesian culture and they will grow the same concept.

The teaching process as the effort to help, to guide, and to train the children is based on the context of children's socio-culture. Their socio-cultural concept is established based on the knowledge gained through observation to the environment. The socio-culture portrayed by the learning process at the Golden 
Kids School applies the concept of Vygotsky's Zone of Proximal Development (ZPD). Children's potential capacity can be developed through the help of adults and more capable people. ZPD is the gap between the actual development level shown by how children solve problems independently and the potential development level shown by how children solve problems with the help of adults or work with peers or more capable people. Thus, their learning development requires others and is impossible to be done alone by themselves. Problems faced by children such as the difference of traditional costumes, traditional food, and even different utterances are explained by the teachers so that they can develop their concept of knowledge concerning the socio-cultural diversity of the nation.

Children also need to have dialogue to express their feelings and ask questions to their teachers. Children are accustomed to have dialogue to their environment to solve the problems. This teaching process in Vygotsky's theory is called scaffolding. Scaffolding is a temporary help. Teachers provide assistance to the students and support their learning development to reach the next stage or level. Vygotsky insists that assistance should not be given if the children have well developed.

The socio-culture at the Golden Kids School is conducted with the practices of daily life. They grow and learn together although they come from different ethnic groups. Living an orderly life, respecting to others and caring for the environment will establish good citizenship. Children are also instilled the value of love and keep the culture so that they have love for their nation which has cultural diversity. Based on the descriptions above, the Golden Kids School is an international school that initiated the education model that emphasizes on socio-cultural diversity in the early childhood education programs. International schools need to make some adjustments in accordance with the Indonesian socio-culture so that children behave into it. Differ- 
ent ethnic and racial backgrounds of the students create learning development which can instill positive values. It makes the Golden Kids School different from other international schools. Thus, the socio-cultural diversity teaching becomes an emphasis in teaching and learning practices at the Golden Kids School in Surakarta.

The concept initiated by Golden Kids Early Childhood Education with elaboration by the author becomes an important contribution in this research. This is an offer for similar schools to teach about diversity in education from an early age by combining Montessori Method, Ki Hajar Dewantara, High Scope, Red Star, Reggio Emillia and Vygotsky and human's three psychological potentials proposed by Ki Hajar Dewantara i.e. cipta (cognition), karsa (conation), and karya (psychomotor). This concept can be applied in the early childhood education everywhere to provide understanding and awareness to children about the importance of tolerance and respect to their fellow human beings. In addition, it has a great purpose to counteract radical religious understanding and religious violence.

\section{Conclusion}

The teaching practices with the emphasis on the socio-cultural diversity at the Golden Kids School in Surakarta resulted in an education that could instill the attitude of appreciation for socio-cultural diversity. The socio-cultural diversity should become the strength of the nation, not a source of conflicts so that diversity should be preserved. The methods in the teaching process use various approaches with the emphasis on socio-cultural diversity materials through songs, dances, and stories. Children do not only have an understanding and appreciation of socio-cultural diversity but also cognition, social, emotional, and moral development. The learning materials which emphasize on socio-cultural diversity would not disturb their devel- 
opment, but they become a means for children development in their early childhood instead.

\section{Bibliography}

Cahyaningrum, Eka Sapti, Nur Cholimah, and Martha Christianti. 2014. "Pelatihan Pengenalan Karakter Untuk Anak Usia Dini Melalui Cerita Rakyat Budaya Lokal Bagi Pendidik PAUD Non Formal TPA/KB/SPS Se-Kecamatan Sleman.” Jurnal Pendidikan Anak 3 (1).

Dewantara, Ki Hadjar. 1977. Pendidikan. Yogyakarta: Majelis Luhur Persatuan Taman Siswa.

Karwati, Euis. 2014. "Pengembangan Pembelajaran Dengan Menekankan Budaya Lokal Pada Anak Usia Dini.” EduHumaniora: Jurnal Pendidikan Dasar 6 (1).

Miles, Matthew B., and A Michael Huberman. 1992. Analisis Data Kualitatif. Jakarta: UI Press.

Monks, F.J., Knoers, and Siti H Rahayu. 2006. Psikologi Perkembangan. Yogyakarta: Gadjah Mada University Press.

Morrison, George S. 2014. Early Childhood Education Today. London: Pearson.

Mustadi, Ali. 2011. "Pendidikan Karakter Berwawasan Sosio-Kultur." Majalah Dinamika Pendidikan.

Roopnarine, JL. 2011. Pendidikan Anak Usia Dini Dalam Berbagai Pendekatan. Jakarta: Kencana Prenada Media Group.

Salkind, N J. 2004. An Introduction to Theories of Human Development. London, New Delhi: Sage Publications International Educational and Professional Publisher. doi:10.4135/9781483328676.

Spradley, PJ. 1997. Metode Etnografi. Yogyakarta: PT Tiara Wacana.

Sudiani, Ni Yoman. 2015. "Pendidikan Karakter Melalui Gend- 
THE TEACHING MODEL ON SOCIO-CULTURAL ...

ing Rare Studi Etnografi Pada Anak Usia Dini Di Desa Adat Tenganan Pringsingan, Kabupaten Karang Asem Provinsi Bali." Pendidikan Anak Usia Dini 9 (1).

Wulandari, Rifa Suci, and Hesti Hurustyanti. 2016. "Character Building Anak Usia Dini Melalui Optimalisasi Fungsi Permainan Tradisional Berbasis Budaya Lokal.” Indonesian Language Education and Literature 2 (1). 
This page intentionally left blank 